\title{
Bencana Kabut Asap dalam Bingkai Media Online
}

\author{
Anang Sujoko ${ }^{1}$, Candra Apriliani' ${ }^{2}$, Fikri A.R ${ }^{2}$ \\ 1,2,3 Jurusan Ilmu Komunikasi, Fakultas Ilmu Sosial dan Ilmu Politik, Universitas Brawijaya \\ Jl. Veteran No 1, Malang, Jawa Timur, 65145, Indonesia \\ Email: anangsujoko@ub.ac.id ${ }^{1 *}$; candra.apriliani@gmail.com²; masfikri@ub.ac.id³ \\ * Corresponding author
}

\begin{abstract}
The forest fire incident in Indonesia is an event that has happened repeatedly in every dry season, so the media has an important perspective in presenting the news. This study aims to analyze the Sindonews media framing the incidents of forest fires in Indonesia during October 2015. This study uses the Pan and Kosicki Model framing analysis research method. The results showed that Sindonews framed forest fires at a very dangerous point. A total of 70 Sindonews articles tend to emphasize the theme of the impact of the haze disaster and the government's slow response to this disaster, which are the dominant points of view. Sindonews framed the government's slow response to the government's performance.
\end{abstract}

Keywords: Forestry Flaring; Framing; News; Online Media; Sindonews

\begin{abstract}
Abstrak
Peristiwa kebakaran hutan di Indonesia merupakan peristiwa yang sudah berulangkali terjadi di setiap musim kemarau, sehingga media memiliki perspektif penting dalam menyajikan berita tersebut. Penelitian ini bertujuan untuk menganalisis media Sindonews membingkai peristiwa kebakaran hutan di Indonesia selama Oktober 2015. Penelitian ini menggunakan metode penelitian analisis framing Model Pan dan Kosicki. Hasil penelitian menunjukkan bahwa Sindonews membingkai kebakaran hutan mencapai titik yang sangat bahaya. Sejumlah 70 berita Sindonews cenderung menekankan tema pada dampak dari bencana kabut asap dan lambannya pemerintah dalam menangani bencana ini menjadi sudut pandang yang dominan. Sindonews membingkai lambannya respon pemerintah tersebut dengan kinerja pemerintahan.
\end{abstract}

Kata kunci: Bencana Kabut; Framing; Berita; Online Media; Sindonews

\section{Pendahuluan}

Perkembangan teknologi komunikasi telah mengubah bagaimana manusia berkomunikasi. Media massa yang memiliki kemampuan penyebaran secara masif telah menjadi sumber informasi bagi sebagian besar masyarakat modern. McQuail (2010) menjelaskan metaphora peran media sebagai jendela dunia dan cermin. Artinya, media sebagai jendela atas peristiwaperistiwa dan pengalaman yang membantu kita melihat lebih luas dan jauh. Lippman (1998) mengatakan bahwa pandangan seseorang tentang dunia luar sangat berkaitan dengan informasi apa yang telah tertanam dalam benak seseorang tersebut. Artinya, media mempunyai peran yang tidak kecil dalam menyuplai informasi ke otak manusia dan memori yang tersimpan inilah suatu saat akan terangkat kembali sebagai nilai-nilai dalam membentuk persepsi seseorang. Jonsson (2011) menyatakan media berita memainkan peran penting dalam mendefinisikan masalah dan membingkai isuisu lingkungan sebagai bencana. Kehadiran media pemberitaan online telah menjadi media alternatif bagi masyarakat selain media arus utama dalam mendapatkan informasi semakin memanjakan masyarakat dalam mengakses beragam informasi yang terjadi tingkat lokal, regional, nasional hingga di belahan dunia.

Setelah media massa beramai-rmai mengangkat isu politik dalam Pilpres 2014, maka di tahun 2015 isu pemberitaan pun mengalami pergeseran. Beberapa media masih merasakan euforia kemenangan Jokowi-JK dan beberapa media lain mulai mengangkat isu-isu yang cenderung sensitif terhadap kinerja pemerintahan baru. Isu lingkungan menjadi isu yang menarik perhatian publik tahun 2015. Salah satunya adalah 
kebakaran hutan serta lahan di beberapa daerah, seperti Sumatera dan Kalimantan. Fenomena ini mengakibatkan muculnya kabut asap. Direktur Komunikasi Indonesia Indicator, Rustika Herlambang menyatakan bahwa titik panas kabut asap mencapai puncak pada bulan Oktober 2015 (Kompas, 2015). Di awal Oktober 2015 kabut asap semakin mengkhawatirkan, Badan Nasional Penanggulangan Bencana (BNPB) menyebutkan, Indeks Standar Pencemaran Udara (ISPU) sudah masuk kategori sangat berbahaya karena menembus angka 2.314 (Sindonews, 2015). Permasalahan kabut asap yang merugikan banyak pihak, baik dari segi perekonomian dan kesehatan membuat Presiden Joko Widodo akhirnya menerima bantuan negara lain di bulan Oktober 2015. Di bulan yang sama muncul desakan kepada Pemerintah untuk menetapkan kabut asap sebagai bencana nasional, salah satu desakan itu datang dari DPR dan DPD.

Isu ini memiliki nilai berita (news value) yang tinggi dan menarik perhatian masyarakat karena memberikan dampak negatif yang sangat besar. Kebakaran hutan dan kabut asap tentunya ini menjadi headline di berbagai media, salah satunya pemberitaan di beberapa portal berita online. Hal ini dilansir oleh Kompas bahwa hasil survei yang dilakukan oleh lembaga riset Indonesia Indicator (I2) perusahaan dibidang intelijen media, analisis data, dan kajian strategis berbasis software Artificial Intelligence (AI) yang bertugas untuk menganalisis fenomena politik, ekonomi, sosial di Indonesia menyatakan pemberitaan mengenai kabut asap mendapat ruang sebanyak 6.920 berita atau 18 persen dari seluruh pemberitaan. Indonesia Indicator mencatat volume berita bencana asap tahun ini melonjak sekitar 400 persen dibandingkan tahun sebelumnya di bulan yang sama.

Peneliti tertarik membahas www.sindonews. com yang dikelola oleh PT Media Nusantara Citra Tbk (MNCN) salah satu perusahaan terbaik di Indonesia. MNCN meraih penghargaan sebagai salah satu dari 50 perusahaan terbaik versi Forbes
Indonesia (Sindonews, 2015). MNCN didirikan di Surabaya pada tanggal 2 November 1989 oleh Hary Tanoesoedibjo. Habsari (2012) menyatakan bahwa PT. Media Nusantara Cipta (PT MNC Terbuka) merupakan salah satu konglomerasi media terbesar di Indonesia. Perusahaan ini memiliki bisnis di bidang produksi program, distribusi program, saluran program televisi, surat kabar, tabloid, jaringan radio dan portal berita online, serta perusahaan ini dikatakan sebagai perusahaan media yang terintegrasi secara raksasa. Dalam fenomena konglomerasi media, proses konstruksi realitas pun diselaraskan dnegan pertimbangan-pertimbangan modal, baik yang langsung maupun tidak langsung berkaitan dengan usaha yang ada di bawah konglomerasi tersebut (Hamad, 2004, 26).

Hary memiliki pengaruh tinggi terhadap kepemilikan media PT. MNCN dan karirnya sebagai salah satu ketua umum partai politik. Hal ini tidak menutup kemungkinan pemilik media membangun media untuk melancarkan kepentingannya dalam hal politik dan penyebaran ideologi tertentu, melalui media yang dimiliki. Eriyanto (2008:87) menyatakan ideologi adalah sebuah sistem kepercayaan yang dimiliki oleh kelompok atau kelas tertentu. Pemilik media melalui kerja ideologinya mempunyai kekuasaan lebihbesardalammenyebarkangagasandanpesan.

Hal ini menarik perhatian peneliti untuk mengaitkan masalah dengan teori ekonomi politik media. Dennis McQuail (2010:97) menjelaskan teori masyarakat massa media melihat bahwa fenemona jaringan media yang terpusat di Jakarta mempunyai kecenderunagn untuk melakukan manipulasi dan mengontrol masyarakat. Sementara dalam teori ekonomi politik media memfokuskan hubungan antara struktur ekonomi dan dinamika industri media serta konten ideologis media yang memandang lembaga media sebagai bagian dari sistem ekonomi dalam hubungan erat dengan sistem politik. Lebih jauh dalam teori ekonomi politik kritis (McQuail, 2010) 
Tabel 1. Kelebihan Media Online

\begin{tabular}{|c|c|}
\hline Kelebihan & Makna \\
\hline Kontrol Audiens & Masyarakat lebih leluasa memilih informasi yang cocok \\
\hline Nonlinear & $\begin{array}{l}\text { Menyediakan ruang berita atau cerita yang lebih kontekstual, } \\
\text { lebih panjang }\end{array}$ \\
\hline $\begin{array}{l}\text { Tersimpan dan bisa dicari } \\
\text { lagi informasinya }\end{array}$ & $\begin{array}{l}\text { Mampu menyimpan jumlah data, cerita amat banyak, bisa } \\
\text { diakses ulang }\end{array}$ \\
\hline Ruang tidak terbatas & $\begin{array}{l}\text { Menghadirkan ruang tanpa batas hamparan mapan batasan } \\
\text { waktu }\end{array}$ \\
\hline Cepat & Informasi hadir amat cepat, praktis \\
\hline Kapabilitas multimedia & $\begin{array}{l}\text { Memungkinkan wartawan menggabungkan teks, suara, video, } \\
\text { dan berbagai konten berita yang lain }\end{array}$ \\
\hline
\end{tabular}

melihat fenomena pertumbuhan konglomerasi media MNC Group merupakan salah satu media yang melakukan ekspansi horizontal, vertikal dan diversifikasiuntuk memperkuat dan memperluas jaringan medianya (Lase dan Rio, 2014). MNC Group telah melakukan diversifikasi medianya mulai dari media cetak, media elektronik, hingga media online.

Hapsari (2012) menjelaskan konsentrasi kepemilikan media sangat berpengaruh terhadap isi atau program yang disampaikan kepada masyarakat di mana isi atau program tersebut merepresentasikan kepentingan ekonomi maupun politik pemilik media yang berakibat pada tidak tersampaikan penuh kebenaran informasi kepada masyarakat karena adanya proses framing yang dilakukan oleh media disesuaikan dengan kepentingan pemiliknya. Berdasarkan fakta dan permasalahan yang telah ditemukan, peneliti tertarik untuk membahas bagaimana framing pemberitaan di media online www. sindonews.com dalam menyampaikan peristiwa bencana kabut asap periode Oktober 2015.

Posisi media sebagai bagian dari masyarakat tidak bisa terlepas dari keberadaan sub sistem sub sistem yang ada dalam masyarakat. Artinya, ada relasi antara media dengan masyarakat dan institusi yang ada di masyarakat. Dalam praktek kehidupan masyarakat bermedia, McQuail (2010) mengatakan media memiliki pengaruh yang sangat signifikan dalam membentuk opini masyarakat. Dahlgren (2005) bahkan mengungkapkan kepentingan komersial media massa telah menimbulkan degradasi ranah publik. Namun demikian, kehadiran teknologi internet telah mengubah dominasi tunggal kekuatan industri atau pengelola media. Masyarakat pengguna media atau khalayak mempunyai hak akses ke media dan bahkan mampu menjalankan fungsi media sebagai produsen informasi sekaligus mendistribusikan ke khayalak secara masif. Di sinilah kita melihat bahwa media pemberitaan online tidak serta merta dikatakan sebagai pihak tunggal yang mempengaruhi khalayak. Bahkan melalui teknis perekaman jumlah akses pembaca berita online, sebuah tema berita akan bisa dikategorikan sedang hit atau tidak diminati khalayak.

Media baru menawarkan beberapa keunggulan dibanding dengan media arus utama. Beberapa karakteristik media baru adalah kecepatan, kemudahan akses dan jangkauan penyebarannya. Sedangkan media berita online yang dikategorikan sebagai media baru ada tiga macam yakni mainstream general news site, a news agregator, dan a specialized news source (Dominick, 2005). Fikri (2015) mencatat beberapa kelebihan media berita online di Tabel 1 .

Kekuatan media berita online mampu menyampaikan informasi mengenai kabut asap secara cepat dan terus-menerus menjadikan berita kabut asap menjadi headline di media berita online. Media berita online yang dapat mengakses informasi secara cepat memudahkan khalayak dalam menerima informasi terbaru serta turut aktif dalam menanggapi berita tersebut. 
Berita online dalam penyampaian informasinya tidak terbatas ruang dan waktu, sehingga informasi yang disampaikan dapat diketahui oleh khalayak di berbagai tempat secara bebas. Hal ini salah satu alasan informasi tempat terjadinya bencana dapat diketahui saat itu juga. Berita online juga dapat menggabungkan berbagai informasi, didalam konten beritanya menjadi lebih luas, misalnya penggunaan hyperlink yang bermanfaat untuk menggali informasi lainnya dihalaman web yang berbeda

Berita yang dimuat di media berita online juga merupakan hasil konstruksi dari para pekerja media, yakni para jurnalis, baik reporter maupun redaktur, yang menyusun berita tersebut. Hal ini dijelaskan oleh Fikri (2015), yaitu melalui berita-berita yang tampil secara serempak dan interaktif tersebut, new media memiliki kekuatan mempengaruhi konstruksi realitas sosial khalayaknya. Artinya, apa yang dinilai penting oleh media dalam pemberitaannya, sangat mungkin mendapat perhatian dari khalayak, hingga materi berita itu dinilai mendasar dan dianggap sebagai kebenaran. Arus besarnya adalah semakin besar media menonjolkan suatu isu konflik, makin besar pula perhatian user pada isu pilihan media tersebut.

Hal ini membuat setiap media termasuk media online, mempunyai kekuatan untuk menyusun realitas dari suatu peristiwa menjadi berita yang bermakna untuk dibaca oleh khalayak. Produksi berita itu bukanlah sesuatu yang netral, melainkan ada ideologi yang secara sadar atau tidak sadar tengah dipraktikan oleh wartawan. Berita yang dilaporkan media massa sebenarnya bukan murni bebas nilai. Menurut Abrar (1993:7) sebab semua media tersebut memiliki kebijaksanaan redaksional tersendiri.

Media sebenarnya berada di tengah realitas sosial dengan berbagai kepentingan, konflik, dan fakta yang beragam. Peran jurnalisme sebagai penyedia forum informasi ketika isu mengenai dunia sosial secara berkelanjutan ditampilkan dan diperdebatkan.
Kekuasaan politik dan media massa mempunyai hubungan yang sangat erat dan keduanya memiliki kekuatan (Susanto, 2013). Kekuasaan politik sangat menonjol dalam hal pengendalian isi media yang mempunyai kekuatan untuk tidak bisa dilawan oleh media massa. Hal ini juga dijelaskan oleh Baran dan Davis (2010), sebagai berikut:

Elite lain memiliki pengetahuan yang luas mengenai bagaimana berita diproduksi, mereka cukup tahu seberapa besar komitmen wartawan terhadap praktik produksi berita yang mereka lakukan. Hal ini memungkinkan mereka untuk merancang peristiwa yang akan diberi frame sesuai keinginan mereka dan secara efektif menyarankan pada jurnalis bagaimana sebuah peristiwa diberi frame.

Hal tersebut menjelaskan adanya sekelompok elite yang berkepentingan dalam industri media dapat melibatkan jurnalis dalam membangun "drama" dalam berita yang mengaburkan realitas tersebut. Dalam hal ini menyebabkan media bukanlah saluran yang murni bebas nilai. Abrar (1993: 7) menyatakan semua media tersebut memiliki kebijaksanaan redaksional tersendiri, betapapun pentingnya sebuah berita, kalau bertentangan dengan kebijaksanaan redaksional media, berita itu tidak akan pernah dimuat. Menurut Hamad sebuah media bisa jadi dipengaruhi oleh berbagai faktor internal berupa kebijakan redaksional tertentu mengenai suatu kekuatan politik, kepentingan politik para pengelola media, relasi media dengan sebuah kekuatan politik tertentu (Hamad, 2004 :2).

Dalam perspektif ekonomi politik komunikasi, media dipandang sebagai sebuah industri yang pada akhirnya berorientasi pada pemikiran ekonomi. Ekonomi merupakan satu kesatuan sosial dan politik serta hubungan kekuasaan yang terstruktur. Dalam hal ini Mosco (2009) memformulasikan ekonomi politik media ke dalam tiga aspek yakni komodifikasi, strukturasi dan spasialiasi. Sementara dalam perspektif ekonomi politik 


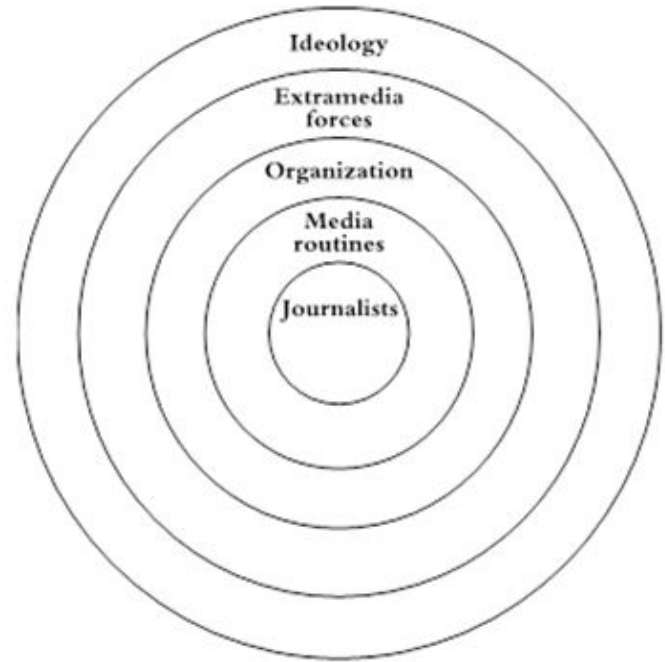

Gambar 2. Faktor-faktor yang mempengaruhi isi media

Sumber: Shoemaker \& Reese, (1996)

kritis, media berperan sebagai produsen ideologi dan perwakilan kepentingan parsial (Litschka, 2019). Struktur oligopolistik dari banyak industri media mendukung proposisi ini, karena perilaku kolusif dibuat lebih mudah dalam struktur seperti itu. Hal ini juga ditulis oleh Fahrudin (2014) bahwa ekonomi politik memiliki cara pandang tersendiri terhadap media yang tertarik pada bentuk-bentuk perluasan konsentrasi perusahaan media, terutama sangat tertarik dengan kepemilikan yang merupakan elemen utama dalam definisi konsentrasi media. Hal ini membuat perhatian pada konsentrasi kepemilikan yang dapat membatasi arus informasi dengan membatasi keberagaman produksi dan distribusi.

Konglomerasi dapat melemahkan fungsi kontrol media, terutama yang terkait dengan kepemilikan media karena bisnis media terkonsentrasi pada pelaku bisnis dan aktor politik yang mempunyai akses kuat ke lingkar kekuasaan. Melalui pola kepemilikan dan produk-produk yang disajikan, media adalah perangkat ideologis yang melanggengkan dominasi kelas pemodal terhadap pemodal terhadap pemegang kekuasaan untuk memuluskan lahirnya regulasi-regulasi yang pro pasar (Sudibyo, 2004). Hal ini menyebabkan isi media tidak mencerminkan peristiwa secara netral dan sempurna, karena media menyeleksi apa yang akan dimasukkan dalam isi media.

Shoemaker dan Reese (1996) menyatakan faktor-faktor lain yang memengaruhi isi media dan model ini memiliki jenjang yang direpresentasikan oleh lingkaran konsentrik masing-masing (Gambar 2). Pertama, jurnalis atau individual pekerja media sangat berpengaruh bagaimana dia akan mengkonstruksi sebuah realitas yang dilihatnya di lapangan. Pengaruh sikap pribadi, nilai-nilai dan keyakinan dari seorang komunikator, sikap yang dianggap sebagai latar belakang pengalaman pribadi. Kedua, faktor rutinitas media (media routine) yang berkaitan dengan keseharian dari mekanisme pembentukan berita. Kebijakan redaksional tersebut dioperasionalkan dalam mekanisme kerja redaksi yang dimulai dari proses perencanaan berita. Kenyataannya pada alur produksi berita, sebuah berita yang terbentuk harus melalui suatu proses gatekeeping, yaitu rangkaian penjaga gerbang yang muncul mulai dari jajaran reporter, redaktur hingga pemimpin redaksi.

Ketiga, faktor organisasi media terdiri dari komponen kelembagaan organisasi itu sendiri, struktur organisasi, hingga sistem keorganisasian yang diterapkan. Aspek redaksional pemberitaan adalah bukan satu-satunya faktor yang mempengaruhi proses produksi berita. Terdapat unit-unit lain, seperti sirkulasi iklan, merupakan aspek lain yang turut berperan dalam proses pengambilan keputusan redaksional. Keempat, faktor ideologi, yang seringkali diartikan dengan kerangka referensi yang ada di dalam masing-masing individu tersebut dalam melihat suatu realitas dan bagaimana individu-individu tersebut menyikapi realitas tersebut. Melalui faktor ideologi, dapat dilihat kekuatan yang dominan di masyarakt dan sekaligus di media massa, sehingga kekuatan tersebut mampu berperan dalam penentuan agenda media tersebut. 
Dilihat dari sudut pandang ekonomi politik media dalam penelitian ini, Sindonews.com merupakan portal berita yang dikelola oleh PT. MNC sebagai perusahaan konglomerasi terbesar. Perusahaan ini memiliki bisnis di bidang produksi program, distribusi program, saluran program televisi, surat kabar, tabloid, dan jaringan radio, serta perusahaan in dikatakan sebagai perusahaan media yang terintegrasi secara raksasa. Adanya konglomerasi tentu mempengaruhi kesamaan isi media yang ditampilkan di semua saluran PT. MNC dapat membatasi arus informasi.

Kekuasaan terpusat pada konglomerasi merupakan elemen utama dalam bentuk konsentrasi media. Hary Tanoesoedibjo merupakan pimpinan di Grup Perusahaan media terbesar se-Asia Tenggara. Rosali (2014) menyatakan bahwa Hary Tanoesoedibjo memiliki kerajaan media terbesar se-Asia Tenggara yang meliputu PT. Media Nusantara Citra Tbk, PT. Global Mediacom Tbk, PT MNC Sky Vision, RCTI, Viva News, dan Global TV. Harry tidak hanya menjabat sebagai pimpinan media perusahaan melainkan juga seorang elite politik yang aktif dalam dunia politik dan tentunya akan mempengaruhi ideologi media di bahwa kepemimpinan Harry.

\section{Metode Penelitian}

Penelitian ini menggunakan metode analisis framing Zhongdang Pan dan Gerald M. Kosicki. Metode ini melihat bagaimana seseorang memaknai suatu peristiwa dapat dilihat dari perangkat tanda yang dimunculkan dalam teks. Wartawan menggunakan kata, kalimat, lead, hubungan antarkalimat, foto, grafik, dan perangkat lain untuk membantu dirinya mengungkapkan pemaknaan mereka sehingga dapat dipahami (Eriyanto, 2012: 293).

Unit analisis data dalam penelitian ini merujuk pada unsur teks seperti, headline, lead, latar informasi, kutipan, hubungan antar kalimat, idiom, gambar, dan grafik yang terdapat di dalam Berita Bencana Kabut Asap pada Portal
Berita Sindonews.com periode Oktober 2015. Sumber data penelitian ini adalah data primer berupa 34 teks pemberitaan Bencana Kabut Asap pada Portal Berita Sindonews.com Periode Oktober 2015. Data primer ini termasuk data mentah ( $r a w$ data) yang harus diproses sehingga menjadi informasi bermakna (Kriyantono, 2010: 42). Teknik pengumpulan data pada penelitian ini berupa studi dokumentasi. Data bermuatan kualitatif disebut juga dengan data lunak, keberadaan data kualitatif dapat diperoleh melalui pemaknaan peneliti terhadap dokumen (Pujileksono, 2015:151). Adapun instrument teknik analisis data dari Model Pan dan Kosicki meliputi analisis sintaksis, tematik (tema pemberitaan), skrip, dan retoris.

\section{Hasil Penelitian dan Pembahasan}

Fokus penelitian ini yaitu cara media melakukan framing berita terkait bencana kabut asap dalam media online Sindonews.com periode Oktober 2015. Pertama, dari analisis sintaksis yaitu pandangan Sindonews.com diwujudkan dalam skema atau bagan dalam berita. Judul berita atau headline pada Sindonews menunjukkan ada dua topik besar di bulan Oktober 2015, yaitu dampak kabut asap dan upaya pemerintah dalam menangani kabut asap. Dua topik besar tersebut memiliki keterkaitan satu sama lain yang membentuk pesan bermakna untuk pembaca. Eriyanto (2012: 297) menyatakan bahwa headline digunakan untuk menunjukkan bagaimana wartawan mengkonstruksi suatu isu, seringkali menekankan makna tertentu. McQuail (2010) menilai bahwa cara inilah yang pada akhirnya memosisikan media sebagai kekuatan dalam mempengaruhi masyrakat. Bagian berita lain yang penting setelah pewarta Sindonews. com menuliskan headline dan lead berita akan didukung oleh kutipan sumber dari beberapa narasumber yang terpercaya dalam bidangnya. Eriyanto (2012:298) menyatakan bagian pengutipan sumber dalam penulisan berita dimaksudkan untuk membangun objektivitas, prinsip keseimbangan dan tidak memihak. 
Kedua adalah struktur tematik. Ada 34 tema dalam teks berita yang mengarah pada - topik terkait dampak kabut asap di bulan Oktober 2015. Inti dari teks yang diuraikan oleh tema-tema tersebut terkait kondisi kabut asap yang masih belum mereda bahkan semakin tebal di bulan Oktober 2015. Selanjutnya, ada 32 tema dalam teks berita yang mengarahkan pembaca dalam melihat usaha yang dilakukan oleh pemerintah menangani kabut asap di bulan Oktober 2015. Penulis menemukan pesan implisit pada inti teks dari tema-tema tersebut yaitu pesan yang mengarah pada kritikan lambannya usaha pemerintah dalam menangani kabut asap menjadi salah satu penyebab kabut asap masih tebal di bulan Oktober 2015. Pada tema terakhir, empat tema berita secara umum terkait dengan tambahan informasi bagi pembaca, seperti seperti tips sehat saat kabut asap, kabut asap tidak sebabkan kematian secara umum, kualitas udara di Jakarta masih dikotori polusi kendaraan, dan kabut asap menipis, siswa mulai bersekolah. Hamad (2004: 21) menyatakan framing bisa dipandang sebagai sebuah strategi penyusunan realitas sedemikian rupa melalui pilihan kata dan cara penyajian realitas serta memunculkan sebuah makna.

Ketiga, dari struktur skrip, seperti yang telah di bahas sebelumnya media berita online memiliki salah satu keunggulan yaitu dalam penyampaian informasi secara cepat. Kecepatan ini juga memunculkan kekurangan lain, yaitu dari sisi kelengkapan berita media online yang sering kali kurang diperhatikan oleh pewarta. Hal ini terjadi pada pemberitaan di portal berita Sindonews, ada beberapa berita yang memiliki kekurangan dalam unsur skrip 5W+1H. Apabila diperhatikan dari keseluruhan hasil analisis teks berita, Sindonews.com menekankan pada unsur 'where' yang mengarah pada lokasi terjadinya bencana kabut asap dan unsur 'how' yang menggambarkan kondisi terkini di wilayah yang terkena dampak kabut asap.
Keempat, dari level retoris, pembingkaian yang dilakukan pada teks berita bencana kabut asap Oktober 2015 ada dua topik besar yang ditekankan dari tema-tema tersebut, yaitu dampak kabut asap dan up aya pemerintah dalam menangani kabut asap. Penekanan kata tertentu dapat dilihat dari headline beberapa tema berita terkait kabut asap dari sisi dampak yang ditimbulkan selama bulan Oktober 2015. Berikut adalah temuan penonjolan kata pada headline, pertama, penggunaan kata 'tewas' pada korban akibat kabut asap, penggunaan kata 'ancam' memberi makna bahwa kabut asap sangat merugikan, penggunaan kata 'resahkan' yang mengarahkan pembaca bahwa warga sudah merasa terganggu, penggunaan kata 'meradang' terkait segi pariwisata semakin memburuk akibat kabut asap, penggunaan kata 'menggila' memberi makna bahwa kabut asap sudah terlalu parah atau semakin meningkat ketebalannya. Pada sebuah informasi, media online sengaja menggunakan kata-kata yang bersifat persuasif untuk mendorong pembaca membuka halaman tersebut (Wenerda, 2015).

Selanjutnya, penekanan kata tertentu juga dapat dilihat dari headline beberapa tema berita terkait upaya pemerintah dalam menangani kabut asap di bulan Oktober 2015, penggunaan kata 'desak' diartikan sebagai dorongan paksa, penggunaan kata 'gagap' memiliki makna bahwa pemerintah masih tidak cepat atau lamban, penggunaan kata 'pesimistis' memiliki makna pada usaha pemerintah yang tidak percaya diri, penggunaan kata 'sindir' yang memberi makna sebuah kritikan pada kinerja pemerintah, penggunaan kata 'tak peka' yang mengarahkan pembaca bahwa pemerintah kurang peduli, penekanan kata 'setengah hati' memberi makna bahwa pemerintah masih belum serius, penekanan kata 'pemakzulan' yang diartikan sebagai pemberhentian jabatan Jokowi sebagai presiden. 
Pada sisi retoris lain, pembingkaian juga dilakukan oleh penggunakan gambar, ilustrasi, dan foto. Pembingkaian yang dilakukan oleh Sindonews.com juga dilihat dari pemilihan gambar atau foto sebagai pelengkap berita. Pengambilan foto yang dilakukan oleh media menekankan pada keadaan atau lokasi kabut asap. Sebagian besar foto memperlihatkan bagaimana kabut asap tebal masih menyelimuti rumah, lapangan, jalan raya, sekolah di daerah yang terkena imbas dari kebakaran hutan dan lahan. Hal ini dilakukan agar pembaca lebih merasakan dampak dari kabut asap saat membaca berita tersebut. Pada foto juga terdapat 'people in the news' biasanya mengarah pada tokoh orang penting yang memberikan keterangan sebagai narasumber berita. Jemat (2014) menyatakan framing sebagai metode penyajian realitas dimana kebenaran tentang suatu kejadian dibelokan secara halus, salah satunya dengan bantuan foto, karikatur, dan alat ilustrasi lainnya.

Berdasarkan pembingkaian yang dijabarkan melalui perangkat framing di atas terdapat hal yang paling menonjol melalui tema besar yang dibuat oleh Sindonews.com. - Tema dampak kabut asap menyertakan sumber informasi berasal dari pihak dari warga di lokasi bencana kabut asap yang mengeluh kabut asap tak kunjung usai dan pihak lembaga lain yang bertugas dalam menyampaikan keadaan kabut asap di lokasi bencana, seperti Badan Nasional Penanggulangan Bencana (BNPB), Badan Penanggulangan Bencana Daerah (BPBD), Badan Meteorologi, Klimatologi, dan Geofisika (BMKG), serta Badan Pusat Statistik (BPS). Jika dicermati dari sisi dampak berita, narasumber yang dipilih oleh pewarta sesuai dengan nilai berita dari bencana kabut asap karena untuk mendukung isi berita terkait kredibilitas dan validitas sumber.

Kedua, tema upaya pemerintah dalam menangani kabut asap. Tema ini lebih menonjolkan kritikan dari narasumber berasal dari lembaga luar media yaitu anggota parlemen dan perwakilan anggota partai politik yang mendesak pemerintah untuk menjadikan kabut asap sebagai bencana nasional dan mengkritik kinerja pemerintah yang masih belum membuahkan hasil dalam meredakan kabut asap di daerah bencana. Nama yang dimunculkan dalam berita, seperti Ketua Umum Partai Perindo Hary Tanoesoedibjo, Wakil Ketua MPR Hidayat Nur Wahid (Fraksi Partai PKS), Wakil Ketua DPR Agus Hermanto (Fraksi Partai Demokrat), Wakil Ketua Komisis IV DPR Herman Khaeron (Fraksi Partai Demokrat), Wakil Ketua DPR Fadli Zon (Wakil Ketua Umum Partai Gerindra), Ketua Umum DPP Partai Golkar, Ketua Umum Partai Bulan Bintang Yusril Ihza, Wakil Ketua Partai Gerindra Edhy Prabowo, Wakil Wali Kota Padangsidimpuan Muhammad Iskandar Nasution, Ketua Komisi III DPRD Padangsidimpuan Khoiruddin Nasution (Fraksi Partai Demokrat), Anggota Komisi III DPR Adies (Fraksi Partai Golkar).

Dalam memilih narasumber tergantung dari pewarta, tetapi tetap sesuai dengan tujuan dari redaksi dalam organisasi media tersebut. Hal ini dilakukan pewarta untuk mencapai kesesuaian tujuan pemberitaan pada media yang bersangkutan. Hal ini juga dijelaskan oleh Shoemaker dan Reeseyang ada pada level rutinitas media (1996: 255) menyatakan bahwa semakin pekerja mengikuti aturan dari rutinitas organisasi mereka, semakin besar konten yang ditulis oleh pekerja akan dimuat oleh media. Rutinitas media menjadi salah satu alasan yang mempengaruhi isi konten yang telah dibuat oleh individu.

Sindonews.com telah memilih pihakpihak di luar organisasi media untuk membentuk makna tertentu karena secara tidak langsung pembingkaian dapat dilihat melalui bagaimana media memilih narasumber untuk mempengaruhi isi konten media. Ada kemungkinan pengaruh HT sebagai pemilik media, sehingga menguhubungkan beberapa aktor politik sebagai narasumber berita terkait upaya pemerintah dalam menangani kabut asap. Ini juga dijabarkan oleh Shoemaker dan Reese 
pada level organisasi (1996:177) menyatakan semua anggota di dalam organisasi diharuskan menjawab kepentingan pemilik dan manajemen puncak yang bertugas mengkoordinasi seluruh perusahaan dan meningkatnya kompleksitas struktur kepemilikan perusahaan membuat proses koordinasi menjadi lebih kompleks.

Pemilihan narasumber berasal dari anggota partai politik seperti, Gerinda, PKS, PBB, dan Golkar yang memiliki afiliasi khusus dengan HT sebagai Ketua Umum Perindo dan pemilik media Sindonews.com. Seperti yang dijelaskan sebelumnya, bahwaHT membawa masuk Perindo ke dalam Koalisi Merah Putih (KMP) pada Mei 2015 karena memiliki visi yang sejalan yaitu mengkritisi kinerja pemerintah. KMP merupakan koalisi yang mendukung Prabowo SubiantoHatta Rajasa pada pilpres 2014 yang terdiri dari Partai Gerindra, PAN, PPP, PKS, PBB, Golkar, dan Perindo. Ada kemungkinan HT membawa masuk ideologi yang dianut dalam mengkritisi kinerja pemerintah ke dalam konten pemberitaan Sindonews.com, sehingga mempengaruhi pemilihan narasumber terkait kinerja pemerintah dalam menangani kabut asap. Shoemaker dan Reese pada level extramedia (1996: 258) menjelaskan adanya sumber kekuatan ekonomi atau politik yang besar sangat memungkinkan elite untuk mempengaruhi laporan berita. Secara tidak langung, Sindonews.com mencerminkan ideologi yang dianut oleh HT sebagai pemilik media dan aktor politik. Hal ini juga juga dijabarkan oleh Shoemaker dan Reese pada level organisasi (1996: 257) menyatakan bahwa sikap pribadi dan nilai-nilai dari pemilik media berita dapat tercermin tidak hanya dalam editorial dan kolom tetapi juga dalam news dan features.

Ada penerapan ideologi tertentu yang dimasukkan oleh Sindonews.com dengan menanamkan perspektif negatif pada pemerintahan Jokowi-JK. Penerapan ideologi pada sebuah media memiliki keterkaitan erat dengan pihak yang memegang kekuasaan tertinggi di suatu media. Shoemaker dan Reese pada level idelogi (1996: 215) menyatakan pada tingkat ideologi melihat bagaimana kekuasaan yang dimainkan melalui media, sehingga peristiwa ditafsirkan dari perspektif kepentingan berkuasa. Melalui kepentingan yang berkuasa ini penulis mengarah pada kepemilikan Sindonews. com yang dipimpin oleh HT. Kepemilikan media memengaruhi isi konten dalam media. Hal ini dapat dilihat dari penyudutan atau pemberitaan negatif terkait pemerintahan Jokowi-JK yang merupakan lawan politik HT. Selain itu, HT juga mempunyai visi bersama partai politik yang didirikannya untuk mengkritisi kinerja pemerintah yang secara tidak langsung ada kemungkinan memengaruhi Sindonews. com dalam mengkritisi kinerja pemerintahan Jokowi-JK. Shoemaker dan Reese (1996: 215) menyatakan pada tingkat ideologis meneliti bagaimana sumber kekuatan bertindak dalam kepentingan mereka sendiri, bukan sebagai individu tetapi mencakup satu organisasi, seperti rutinitas, nilai-nilai dan struktur organisasi untuk mempertahankan sistem kontrol dan reproduksi ideologi dominan. Hal ini memungkinkan penanaman ideologi yang dilakukan oleh pemilik media mempengaruhi seluruh struktur organisasi dalam menghasilkan konten berita.

Penelitian ini berfokus pada interpretasi sebuah teks dalam pemeberitaan media online dan tidak sedang dalam mengkritisi motivasi media melakukan framing sehingga data yang dapat ditampikan masih sebatas pada permukaan sebuah teks tanpa menghubungkan dengan ideologi media dan pekerja media.

\section{Simpulan}

Berdasarkan 70 berita yang diterbitkan oleh Sindonews.com mempunyai kecenderungan pada tema terkait dampak kabut asap untuk menarik emosi pembaca dengan menuliskan kerugian dan jumlah korban jiwa yang diakibatkan oleh kabut asap. Selanjutnya, tema terkait upaya pemerintah dalam menangani kabut asap, peneliti menemukan pesan secara 
implisit yang dibuat oleh pewarta, yaitu ada 21 dari 32 tema berita menonjolkan pesan yang menunjukkan bahwa pemerintah lamban dalam menangani kabut asap yang sudah dijanjikan akan selesai pada bulan Oktober 2015.

Media massa memiliki fungsi sebagai watchdog yang bertugas mengawasi dan mengontrol kinerja dari lembaga eksekutif. Pada pemberitaan Sindonews.com, pewarta menggiring pembaca dengan mengaitkan bencana kabut asap dan pemerintahan JokowiJK yang genap satu tahun pada bulan Oktober 2015 karena banyak program kerja Kabinet Kerja yang belum menyentuh kebutuhan dan harapan rakyat, terutama dalam penanganan kabut asap.

Media memiliki ideologi yang menyebabkan berita bukan murni sebagai cerminan hasil realitas melainkan ada representasi ideologi media yang bersangkutan. Ideologi bisa menggambarkan bahwa ada kemungkinan keterlibatan pemilik media mempengaruhi isi media. Keterlibatan HT tidak hanya sebagai pemilik media online Sindonews.com melainkan juga sebagai pemimpin partai politik yang didirikannya, yaitu Partai Perindo. Seperti yang telah dijelaskan sebelumnya bahwa kekuasaan politik dan media massa mempunyai hubungan sangat erat. Hal ini memungkinkan munculnya kecenderungan kritikan pemberitaan Sindonews.com pada Pemerintahan JokowiJK karena merupakan lawan politik dari HT yang merupakan pemilik dari Sindonews.com.

Pembingkaian yang dilakukan Sindonews. com terkait bencana kabut asap menggunakan perangkat framing Zhongdang Pan dan Gerald M. Kosicki adalah fokus menampilkan kerugian yang disebabkan oleh kabut asap. Hal ini diperlihatkan melalui foto pada setiap berita kebanyakan menampilkan foto dari daerah kabut asap yang masih diselimuti kabut asap tebal. Selanjutnya, dari unsur skrip juga berfokus pada unsur 'where' dan 'how' yang menggambarkan lokasi kabut asap dan keadaan terkini dari lokasi tersebut. Penelitian ini masih terbatas pada kajian teks media, sehingga penelitian selanjutnya bisa diperdalam dengan menggunakan kajian analisis wacana untuk mengungkapkan ideologi media di balik pemberitaan kebakaran hutan. Hal ini menarik karena konteks politik antara pemilik MNC Group yang membawahi Sindonews dan partai yang berkuasa memilikikepentingan persaingan.

\section{Daftar Pustaka}

Abrar, A. N. (1993). Mengenal Jurnalisme Lingkungan Hidup. Yogyakarta: Gadjah Mada University Press. Abrar, N.A. (2008). Memberdayakan Masyarakat LewatPenyiaran Berita BencanaAlam, 11 (3).

Davis,D.K.\&Baran, S.J.(2010).Teorikomunikasi massa: dasar, pergolakan, dan masa depan (ed. 5). Jakarta: Salemba Humanika. Dahlgren, P. (2005) 'The Internet, Public Sphere And Political Communication'. Political Communication, 22 (2), 147-62.

Dominick, J. R. (2005). The Dynamics of Mass Communication: Media in The Digital Age, New York: McGraww Hill. Eriyanto. (2012). Analisis Framing: Konstruksi, Ideologi, Dan Politik Media. Yogyakarta: LKiS .

Eriyanto. (2008). Analisis Wacana: Pengantar Analisis Teks Media. Yogyakarta: LkiS.

Fahrudin, D. (2013). Konglomerasi media: studi ekonomi politik terhadap media group. Jurnal Visi Komunikasi, 11 (01).

Fikri, M. (2015). Konflik Agama Dan Konstruksi New Media (Kajian Kritis Pemberitaan Konflik Di Media Berita Online). Malang: UB Press. Gabrillin,A.(2015) Survei:Terburuk, Penanganan Kebakaran Hutan oleh Pemerintah, Kompas.com. (2015). https://nasional.kompas. com $/ \mathrm{read} / 2015 / 10 / 26 / 18022191 /$ Survei. Terburuk.Penanganan.Kebakaran.Hutan. oleh.Pemerintah, diakses 27 Oktober 2015. Hapsari, S. U. H. (2012). Spasialisasi kelompok media MNC. Jurnal Ilmu Sosial dan Ilmu Politik Universitas Pandanaran, 10 (24). 
Hamad, I. (2004). Konstruksi Realitas Politik Dalam Media Massa: Sebuah Studi Critical Analysis Terhadap Berita-Berita Politik. Jakarta: Granit. Jonsson, A. M. (2011). Framing Environmental Risks In The Baltic Sea: A News Media Analysis. Royal Swedish Academy of Sciences, 40, 121-132.

Jemat, A. (2014). Framing media online terhadap pemberitaan mengenai susilo bambang yudhoyono menjelang pemilu legislatif 2014. Jurnal komunikologi, 11 (2).

Kriyantono, R. (2010). Teknik praktis riset komunikasi. Jakarta: Kencana.

Lippmann, W. (1998), Opinion Public, New Jersey: Transaction Publishers Lase, J. \& Rio, O. A. (2014). Ekonomi Dan Diversifikasi Media Massa. Jurnal interaksi, 3(1).

Litschka, M. (2019), The Political Economy od Media Capabilities: The Capability Approach in Media Policy, Journal of Information Policy, 9, 63-94.

McQuail, D. (2010), McQuail's Mass Communication Theory, 6th ed., London: Sage.

Mulyana, D. (2013). Metodologi penelitian kualitatif: paradigma baru ilmu komunikasi dan ilmu sosial lainnya. Bandung: PT Remaja Rosdakarya.

Mosco, V. (2009), The Political Economy of Communication, $2^{\text {nd }}$ ed., London: Sage Publications,

Pujileksono, S. (2015). Metode Penelitian Komunikasi Kualitatif. Malang: Kelompok Intrans Publishing. Rosalia, L. (2014). Konglomerat Media Sebagai Elite Politik: Wacana Dalam Pemberitaan Hary Tanoesodibo Di Koran Sindo. Jurnal E-Komunikasi Program Studi Ilmu Komunikasi Universitas Kristen Petra, 2 (1).
Shoemaker, J. P. \& Reese, D. S. (1996). Mediating the message Theories of influences on mass media content. Diakses pada 29 Oktober 2016, dari https:// journalism.utexas.edu/sites/ journalism.utexas.edu/files/attachments/ reese/mediating-the-message.pdf Susanto, E. H. (2013). Komunikasi Politik: Pesan, Kepemimpinan dan Khalayak. Jakarta: Mitra Wacana Media.

Sindomedia. Diakses pada 11 Desember 2015 , dari http://mnc.co.id/ businesses/sindomedia/id\#content Sahid, R. \& Kiswondari. (2015, Mei 22). KMP tetap jadi mitra kritis pemerintah. Sindonews. com Diakses dari http://nasional.sindonews. $\mathrm{com} / \mathrm{read} / 1004077 / 149 / \mathrm{kmp}$-tetap-jadimitra-kritis-pemerintah-1432266253.

Syafril, A. (2015, Februari 2015). Hary tanoesoedibjo deklarasikan partai perindo. Antaranews.com. Diakses dari http:// www.antaranews.com/berita/478708/harytanoesoedibjo-deklarasikan-partai-perindo.

Wenerda, I. (2015). Ekonomi politik vincent moscow oleh media online entertainment kapanlagi.com. 3 (1).

Yovanda, Y, R. (2015, November 25). MNCN raih penghargaan 50 perusahaan top dari forbes. Sindonews.com. Diakses dari http:// ekbis.sindonews.com/read/1064544/34/ mncn-raih-penghargaan-50-perusahaant op-dari - forbes-1448464595. Yovanda, Y, R. (2015, November 25). Masuk 10 besar MNC group, perbesar sindonews. Sindonews.com. Diakses da r i h t t p :// e k bis.sind on ew s . com/ $\mathrm{read} / 1064554 / 34 / \mathrm{masuk}-10$-besar-mnc- 